\title{
1 Environmental drivers of mussels flesh yield in a coastal upwelling system
}

2 Xosé Antón Álvarez-Salgado*, Uxío Labarta, Vanesa Vinseiro, María José Fernández-

3 Reiriz

4

5 CSIC Instituto de Investigaciones Marinas, Eduardo Cabello 6, E36208 Vigo, Spain

6 *Corresponding author: 引 xsalgado@iim.csic.es;

8 Type of article: Original research paper

9

2

Key words: blue mussel; flesh yield; continental runoff; coastal upwelling; NW Iberian Peninsula

\section{ABSTRACT}

Eastern boundary coastal upwelling ecosystems (EBUEs) are highly sensitive to climate variability, particularly to coastal wind change. Here, we test the response of the flesh yield of blue mussels cultured in the northern boundary of the Iberian-Canary current EBUE to climate-related variables. Significant relationships were found between the annual mean, seasonal build-up and phenology of the mussel flesh yield with meteorological variables such as continental runoff, intensity and direction of coastal winds, and solar radiation. Our analysis shows that better flesh yields occur during years characterised by dry winters, accompanied by early springs and followed by summers dominated by strong northerly winds that produce intense upwelling. Compared with other EBUEs, upwelling has weakened in the study area over the last fifty years, implying an overall decrease in mussel 
24 flesh yield. However, future climate scenarios suggest that coastal upwelling will intensify 25 over the 21th century, particularly during the summer months, which would lead to a recovery of mussel flesh yield.

\section{Introduction}

The flesh yield, i.e. the portion of the total weight that is soft-tissue, is a routinely used condition index of commercial bivalves feeding in dynamic coastal environments (Orban et al., 2002; 2007; Knights, 2012; Filgueira et al., 2013). The flesh yield provides a cost-effective indicator of bivalve culture performance (Sasikumar and Krishnakumar 2011) and is commonly used as a benchmark for management strategies (Halpern et al., 2008; Polasky et al., 2011) and to assess their monetary value (Pérez-Camacho et al., 2013; 2014). The bivalve flesh yield has been also applied in environmental monitoring programs (Smaal and Widdows, 1994) as it integrates physiological responses to food availability and quality with changes in somatic growth associated to the reproductive cycle of bivalves (e.g. Mathieu and Lubet 1993; Fernández-Reiriz et al., 1996; Orban et al., 2002; 2007; Baek et al., 2014; Irisarri et al., 2015). Lucas and Beninger (1985) recommended that the flesh yield of adult bivalves would be adopted for most routine aquaculture work.

The Galician rías, a group of coastal embayments in the NW coast of Spain (Fig. 1), are a World-leading producer of blue mussels, with an annual yield of about 220,000 tons, which represents $40 \%$ of the European and $15 \%$ of the World production (Labarta et al., 2004). The intricate orography of the region, its oceanographic regimen dominated by coastal upwelling-downwelling episodes, and the particular cultivation method on hanging ropes is behind the success of these ecosystems as one of the major producers of marine 
47 proteins per square meter in the World (Tenore and González 1975; Álvarez-Salgado et al.,

48 2011). The high productivity of the region attracted ambitious ecosystem approach studies

49 since the 1970's in the rías of Arousa and Muros (Tenore and González, 1975; Tenore et

50 al., 1982) (Fig. 1). In this context, Blanton et al. (1987) reported for the first time a positive

51 linear relationship between coastal upwelling intensity and mussel flesh yield, i.e. between

52 the regional scale weather pattern and the commercial value of mussels harvested in the

53 Galician rías. Given this dependence, knowledge of regional changes in weather conditions

54 under present (Álvarez-Salgado et al., 2008; Pérez et al., 2010) and future (Álvarez et al.,

55 2016) climate scenarios would be helpful for the management of the local mussel farm 56 industry.

57 Despite the importance of the Galician rías for the world production of blue mussels, 58 studies relating the mussel flesh yield with the regional weather conditions are scarce 59 (Blanton et al., 1987). In this work, we have used an extensive dataset of flesh yield values 60 from mussels cultured in different areas of the Ría de Ares-Betanzos (Fig. 1) collected 61 between the years 2001 and 2012. With this dataset, we have modelled the seasonal 62 variability of the flesh yield and examine its inter-annual variability in the light of the 63 weather conditions in the study area, using solar radiation, coastal winds and river 64 discharge as explanatory variables. These meteorological variables are proposed as proxies 65 of sea surface temperature and food availability, the latter being the environmental 66 variables that control bivalve growth according to previous studies in the area (Aguiar et 67 al., 2015). Our results demonstrate the usefulness of linking mussels flesh yield with the 68 climate conditions of the area to use them as an indicator of the seasonal and interannual 69 variability of mussel meat content. 


\section{Materials and Methods}

\subsection{Mussels flesh yield}

Flesh yield values used in this work were the condition index $(C I)$ values provided by the mussel farmer PROINSA, who owns 95 of the 147 mussel rafts / long-lines anchored in the two cultivation areas, Arnela and Lorbé, of the Ría de Ares-Betanzos (Fig. 1). PROINSA has been monitoring the size and flesh yield of the cultured mussels that have achieved the commercial size $(>50 \mathrm{~mm})$, as well as, the mussels already extracted for commercialization from their mussel rafts since 2001. The flesh yield is calculated as the percentage of the total weight of $1 \mathrm{~kg}$ of live mussels collected in a mussel raft that is meat weight after opening the valves with water vapour. It should be noted that this monitoring programme has been based on the strategic management of the farmer rather than a preconceived scientific design. This resulted in an uneven temporal and spatial coverage of the flesh yield data because the mussel rafts monitored and the times that they were visited depended on the presence of commercial size mussels $(>50 \mathrm{~mm})$ in the trays and the occurrence of red tide events that produced a closure of the mussel cultivation areas. Table A1 and Figure A1 in the Appendix summarises the temporal and spatial coverage of the data used in this work. The crude database, consisting of 2749 flesh yield values obtained from samples of $1 \mathrm{~kg}$ of live mussels, was organised in two groups, coinciding with the cultivation areas of Arnela (964 values) and Lorbé (1785 values), located in the innermost and central segments of the embayment (Fig. 1). Individual values were aggregated to obtain monthly time series over the period 2001-2012 for the two areas. This datagathering approach allowed us to partly overcome the irregular temporal and spatial distribution of the data. 


\subsection{Continental runoff}

Rivers Eume and Mandeo (Fig. 1) are the main tributaries of the Ría de AresBetanzos. The flow at the mouth of River Mandeo was estimated from gauge station $n^{\circ} 464$ at Irixoa, hold by Augas de Galicia (Galician Government). The total drainage basin of this river is $456.97 \mathrm{Km}^{2}$ and the gauge station intercepts only $249.21 \mathrm{Km}^{2}$. Therefore, the ratio of total to gauged areas was used to estimate the flow at the mouth following the Horton's Law (Strahler, 1963). Concerning River Eume, its flow is a combination of regulated and natural flows. Daily volumes of the Eume reservoir, which controls $80 \%$ of the drainage basin, were provided by ENDESA S.A., the company in charge of the management of the reservoir. The natural component of River Eume flow was estimated from the River Mandeo flow by applying again the Horton's Law, considering that the drainage basin of River Eume not controlled by the reservoir is just $94.04 \mathrm{Km}^{2}$. Daily values of continental runoff over the period 2001-2012 were averaged to obtain monthly river flows $(Q r)$ to allow direct comparison with the time series of flesh yield.

\subsection{Offshore Ekman transport}

The West-East $\left(Q_{X}\right.$, in $\left.\mathrm{m}^{2} \mathrm{~s}^{-1}\right)$ and South-North $\left(Q_{Y}\right.$, in $\left.\mathrm{m}^{2} \mathrm{~s}^{-1}\right)$ components of the Ekman transport off NW Spain have been calculated following Bakun's (1973) method:

$$
\begin{aligned}
& -Q_{X}=-\frac{\rho_{A} \cdot C_{D}}{\rho_{W} \cdot f} \cdot \sqrt{V_{X}^{2}+V_{Y}^{2}} \cdot V_{Y} \\
& Q_{Y}=-\frac{\rho_{A} \cdot C_{D}}{\rho_{W} \cdot f} \cdot \sqrt{V_{X}^{2}+V_{Y}^{2}} \cdot V_{X}
\end{aligned}
$$


111 Where $\rho_{A}$ is the density of air $\left(1.22 \mathrm{~kg} \mathrm{~m}^{-3}\right.$ at $\left.15^{\circ} \mathrm{C}\right) ; C_{D}$ is an empirical dimensionless drag

112 coefficient $\left(1.4 \cdot 10^{-3}\right) ; f$ is the Coriolis parameter $\left(9.94610^{-5} \mathrm{~s}^{-1}\right.$ at $43^{\circ}$ latitude $) ; \rho_{W}$ is the

113 density of seawater $\left(\sim 1025 \mathrm{~kg} \mathrm{~m}^{-3}\right)$; and $V_{X}$ and $V_{Y}$ are the average daily westerly and

114 southerly components of the geostrophic wind in a $2^{\circ} \times 2^{\circ}$ cell centred at $43^{\circ} \mathrm{N} 11^{\circ} \mathrm{W}$,

115 representative for the study area (Fig. 1). Average daily geostrophic winds were estimated

116 from atmospheric surface pressure charts, provided at 6-hour intervals by the Spanish

117 Institute of Meteorology. Upwelling-favourable offshore Ekman transport matches up

118 positive values of $-Q_{\mathrm{X}}$ and $Q_{\mathrm{Y}}$ in the western and northern coasts, respectively. Conversely,

119 negative values of $-Q_{\mathrm{X}}$ and $Q_{\mathrm{Y}}$ indicate downwelling-favourable onshore Ekman transport

120 in the western and northern coasts, respectively. $-\mathrm{Q}_{\mathrm{X}}$ and $\mathrm{Q}_{\mathrm{Y}}$ were rotated $30^{\circ}$ clockwise to

121 produce a longitudinal $\left(-Q_{\mathrm{L}}\right)$ and a transversal $\left(Q_{\mathrm{T}}\right)$ component of the Ekman transport to

122 the main axis of the Ría de Ares-Betanzos (Fig. 1). Therefore, a positive value of $-Q_{\mathrm{L}}$

123 indicates an offshore Ekman transport and a negative value of $Q_{\mathrm{L}}$ and onshore Ekman

124 transport in this coastal inlet. As for the case of $Q r$, daily values were averaged to obtain

125 monthly mean $-Q_{\mathrm{L}}$ over the period $2001-2012$.

126

127 2.4. Global radiation

128 Global radiation $(G)$ data was taken from the meteorological station of CIS Ferrol 129 (Fig. 1), run by the Galician Meteo Agency Meteogalicia (http//www.meteogalicia.com), 130 where a pyranometer Schenk 8101 is installed. Again, measurements recorded every 10 131 minutes were averaged to obtain monthly mean values of $G$. 


\subsection{Statistical analyses}

The seasonal cycles of the mussel flesh yield or condition index $(C I)$, continental runoff $(Q r)$, offshore Ekman transport parallel to the main axis of the Ría de Ares-Betanzos $\left(-Q_{\mathrm{L}}\right)$ and global radiation $(G)$ were modelled with a simple harmonic function to obtain the corresponding fitting coefficients for the whole study period (2001-2012) and for each individual year by minimising the residuals in the least squared sense. For the particular case of the $C I$, the equation to be fitted is:

$C l=b_{1}+b_{2} \cdot \sin \left(\frac{2 \cdot \pi}{12} \cdot t+b_{3}\right)$

Where $b_{1}$ is the mean value of the condition index $(A v g$, in $\%) ; b_{2}$ is the amplitude of the harmonic; and $b_{3}$ is the diphase (month when the seasonal minimum is achieved). The average increase rate of $C I\left(R a t\right.$, in $\%$ month $\left.^{-1}\right)$ was calculated as Rat $=\left(2 \cdot b_{2}\right) / 6$. The denominator of Rat, 6 months, is the time interval between the seasonal maximum and minimum of $C I$ as fitted with Eq. 3. Finally, the month when $C I$ was halfway between the seasonal minimum and the seasonal maximum $\left(\varphi\right.$, in month) was calculated as $\varphi=b_{3}+3$. For some particular years, mean $C I$ values are not available for certain months (see Table A1 in the Appendix) because mussels were not of commercial size or the farms were closed to exploitation due to a red tide event. In any case, there were enough monthly mean $C I$ values data each year to produce seasonal cycles with statistically significant values of $A v g$, Rat and $\varphi$. Note that the same harmonic function has been also used to model the seasonal cycles of $Q r,-Q_{\mathrm{L}}$ and $G$.

Furthermore, linear models, with location as a factor, were tested to model the interannual variability of the fitting parameters $A v g, R a t$ and $\varphi$ of the mussel $C I$ in the 
cultivation sites of Arnela and Lorbé with the environmental variables $Q r,-Q_{\mathrm{L}}$ and $G$. The effect of location was tested by means of F-tests for nested linear models. The goodness of fit of the different models was tested with the determination coefficient $\left(R^{2}\right)$, the standard error of the fitting coefficients, and the standard deviation of the residuals. Data analysis was performed using the statistical software R 2.15.2 (R Development Core Team 2011).

\section{Results and Discussion}

\subsection{Seasonal and interannual variability of mussels flesh yield}

Monthly mean flesh yield values for both cultivation areas describe a well-defined seasonal cycle (Fig. A2a \& b in Appendix) that can be modelled with a simple harmonic equation (see Eq. 3) characterised by three parameters: the annual mean $C I(A v g$, in \%), the average increase rate of $C I\left(\right.$ Rat , in $\%$ month $\left.^{-1}\right)$ and the month when the $C I$ was halfway between the seasonal minimum and the seasonal maximum $(\varphi$, in month). The values of Avg, Rat and $\varphi$ that best fit the field data to Eq. 3 were obtained for the whole period 20012012 and also for each individual year.

Harmonic Eq. 3 explained $54 \%$ and $42 \%$ of the variability of the monthly-mean $C I$ values over the whole study period in the cultivation areas of Arnela and Lorbé, respectively (Table 1). The 2001-2012 mean $C I(A v g)$ in Arnela, $23.4 \pm 0.4 \%$, was significantly higher $(p<0.01)$ than in Lorbé, $21.9 \pm 0.3 \%$. The 2001-2012 seasonal increase rate $($ Rat $)$ was also significantly higher $(p<0.05)$ in Arnela, $2.0 \pm 0.2 \%$ month $^{-1}$, than in Lorbé, $1.4 \pm 0.2 \%$ month $^{-1}$. Therefore, mussels cultured in Arnela grew faster and of better commercial quality than in Lorbé. When considering the whole study period, both sites followed the same timing in the increase rate of $C I$, with the seasonal minimum being 
177

178

179

180

181

182

183

184

185

186

187

188

189

190

191

192

193

194

195

196

197

198

199

in mid-March (month 3.3-3.6), the seasonal maximum in mid-September (month 9.3-9.6) and $\varphi$ in month 6.3-6.6 (Table 1).

This seasonal cycle is primarily dictated by the reproductive biology of mussels. In this regard, the reproductive cycle of mussels in the Galician rías starts with the development and ripening of the gonads during autumn-winter. A major spawning event takes place during the spring and, subsequently, gonad restoration leads to a secondary spawning event during late summer or early autumn (Villalba, 1995; Peteiro et al., 2011; Suarez et al., 2013; Irisarri et al. 2015). Therefore, to reflect the biology of the species, harmonic Eq. 3 for the individual years was fitted considering 12 month periods starting on October and ending on the next September instead of a Gregorian calendar (JanuaryDecember) (see Fig. A3 in the Appendix). Eq. (3) for each individual year explained from $62 \%$ to $95 \%$ of the variability of the monthly-mean $C I$ values. Significant inter-annual differences were observed in the values of $A v g, R a t$ and $\varphi$ in both cultivation sites (Fig. 2). Seasonal mean $C I$ values ranged from $20.8 \pm 0.6 \%$ (2007) to $25.8 \pm 0.7 \%$ (2011) in Arnela and from $19.5 \pm 0.9 \%$ (2007) to $23.8 \pm 1.0 \%$ (2011) in Lorbé (Fig. 2a). Both sites evolved in parallel, Avg values being generally higher in Arnela than in Lorbé, and no significant inter-annual trend over the period 2001-2012 was observed. The increase rate (Rat) varied from $0.7 \pm 0.2(2012)$ to $3.3 \pm 0.3 \%$ month $^{-1}$ (2011) in Arnela and from $0.8 \pm 0.4$ (2012) to $2.8 \pm 0.4 \%$ month $^{-1}$ (2011) in Lorbé (Fig. 2b). Again, Arnela and Lorbé evolved in parallel, Rat was usually higher in Arnela than in Lorbé, and there was no significant interannual trend over the period 2001-2012. $\varphi$ varied over a wide range of about four months: between months $4.7 \pm 0.4(2004)$ and $8.9 \pm 0.7$ (2002) in Arnela and between months $5.7 \pm$ 0.8 (2004) and $9.6 \pm 0.4$ (2002) in Lorbé (Fig. 2c). Once more, both sites showed similar 
patterns throughout the year and there was no significant inter-annual trend over the period 2001-2012. The marked interannual differences observed in the three parameters of the harmonic equation, $(A v g, R a t$ and $\varphi)$ is the reason behind the relatively low percentage of the total variability (44-54\%; Table 1) explained by the harmonic equation when the entire study period is fitted to Eq. 3.

\subsection{Environmental drivers of the interannual variability of mussel flesh yield}

In order to model the three parameters that define the seasonal cycle of mussel $C I$, we have analysed the correlation of $A v g$, Rat and $\varphi$ with selected indices that define the seasonal cycles of the primary meteorological variables that define the climate of the study area: continental runoff $(Q r)$, offshore Ekman transport parallel to the main axis of the Ría de Ares-Betanzos $\left(-Q_{\mathrm{L}}\right)$ and global radiation $(G)$.

It has been broadly reported in the literature the seasonality of continental runoff and coastal winds in the NW Iberian upwelling system (Nogueira et al., 1997; ÁlvarezSalgado et al., 2008). For the particular period studied in our work, the harmonic equation (Eq. 3) but applied to $Q$ r explained $41 \%$ of the variability of continental runoff (Fig. A2c in the Appendix), resulting in a 2001-2012 mean flow of $29 \pm 2 \mathrm{~m}^{3} \mathrm{~s}^{-1}$, a seasonal amplitude of $24 \pm 2 \mathrm{~m}^{3} \mathrm{~s}^{-1}$ and a seasonal minimum occurring at month $7.2 \pm 0.2$, which means that the transit from the humid to the dry season occurred in early April (Table 1). Figure 3a shows the time course of the annual mean of $Q \mathrm{r}$ for each individual year over the study period, with values ranging from $17 \pm 3 \mathrm{~m}^{3} \mathrm{~s}^{-1}$ (2012) to $51 \pm 5 \mathrm{~m}^{3} \mathrm{~s}^{-1}$ (2007) and no significant inter-annual trend. For the case of the coastal winds (Fig A2d in the appendix), the harmonic equation explained only $23 \%$ of the total variability of $-Q_{\mathrm{L}}$ over the study 
period. The 2001-2012 mean was not significantly different from zero $\left(-46 \pm 48 \mathrm{~m}^{3} \mathrm{~s}^{-1} \mathrm{~km}^{-}\right.$ ${ }^{1}$ ), the seasonal amplitude was $433 \pm 68 \mathrm{~m}^{3} \mathrm{~s}^{-1} \mathrm{~km}^{-1}$ and the seasonal minimum occurred at month $0.3 \pm 0.6$ (Table 1). This means that, on average over the period 2001-2012, the time of the year when $-Q_{\mathrm{L}}$ was positive - i.e. the upwelling-favourable season- extended from month 3.8 (late march) to month 9.4 (early September). Therefore, the average value of $-Q_{\mathrm{L}}$ from April to August is a suitable index of the intensity of the upwelling season on each particular year (Fig. 3b), which ranged from a downwelling-favourable value of -269 $\pm 116 \mathrm{~m}^{3} \mathrm{~s}^{-1} \mathrm{~km}^{-1}$ (2012) to an upwelling-favourable value of $582 \pm 116 \mathrm{~m}^{3} \mathrm{~s}^{-1} \mathrm{~km}^{-1}(2011)$. Again, there was not a significant inter-annual trend of this index over the study period. Concerning the global radiation $(G)$, the harmonic equation explained $94 \%$ of the variability of the monthly time series over the period 2001 to 2012 . The 2001-2012 annual mean was $12.7 \pm 0.1 \mathrm{MJ} \mathrm{m}^{-2} \mathrm{~d}^{-1}$, the seasonal amplitude was $8.4 \pm 0.2 \mathrm{MJ} \mathrm{m}^{-2} \mathrm{~d}^{-1}$ and the seasonal minimum was at month $0.28 \pm 0.04$, i.e. in early January (Table 1). February revealed as the winter month that exhibited the largest inter-annual differences in $G$ (Fig. 3c), with values ranging from $6 \mathrm{MJ} \mathrm{m}^{-2} \mathrm{~d}^{-1}$ (2000) to $10 \mathrm{MJ} \mathrm{m}^{-2} \mathrm{~d}^{-1}$ (2004) and a increasing inter-annual trend over the study period, although not statistically significant.

Our analyses of the correlation of the fitting parameters of mussel $C I(A v g, \operatorname{Rat}$ and $\varphi)$ with the explanatory meteorological variables $\left(Q \mathrm{r},-Q_{\mathrm{L}}\right.$ and $\left.G\right)$ yielded that the annual mean value of $C I(A v g)$ depended inversely on the annual mean value of the continental runoff (Fig. 2d; $R^{2}=0.57, \mathrm{n}=22, p<0.001$ ), the amplitude of $C I$ (Rat) depended directly on the mean offshore Ekman transport from April to August (Fig. 2e; $R^{2}=0.44, \mathrm{n}=22, p<$ $0.05)$ and the diphase of $C I(\varphi)$ depended directly on the average global radiation in February (Fig. 2f; $R^{2}=0.42, \mathrm{n}=22, p<0.001$ ). Linear models with mussel farm location 
as a factor were used to run these analyses (see materials and methods). It resulted that the

247 effect of location was significant for the models of $A v g$ and Rat, but not for the case of the 248 model of $\varphi$.

249 Although the correlation between the annual average mussel flesh yield and 250 continental runoff is not exceptionally high $\left(\mathrm{R}^{2}=0.57\right)$, it is remarkable that such a 251 significant $(p<0.001)$ correlation has been obtained between an intricate physiological 252 variable and a simple meteorological variable. The negative dependence of the annual 253 average of $C I$ on continental runoff is probably related to the transport of mineral particles 254 of terrestrial origin by rivers, which leads to an increase in the total concentration of 255 particles available for filter feeders but dilutes the amount of organic particles suspended in 256 the water column (Aguiar et al., 2015). Therefore, although the relatively low coefficient of 257 determination $\left(\mathrm{R}^{2}\right)$ of the linear relationship between flesh yield and continental runoff 258 prevent us to make quantitative predictions, it is expected that in those years when 259 continental runoff in higher during the wet season (November to March) the flesh yield of 260 the mussels before the upwelling season is lower, leading to a lower annual mean flesh 261 yield.

262 The connection between upwelling intensity and mussel quality (Fig. 2e) was first 263 established by Blanton et al (1987) in the Ría de Arousa. According to their conceptual 264 model, the higher the intensity of upwelling, the higher the nutrient fertilisation, which 265 leads to enhanced primary production, greater food availability and, consequently, 266 improved flesh yield of the cultured mussels. The first three steps of this conceptual model 267 (from wind to primary production) was tested and demonstrated in the field, specifically in 268 the Ría de Arousa, a decade latter (Álvarez-Salgado et al. 1996). And the close relationship 
269 between coastal upwelling, food availability and mussel growth was also verified 270 empirically (Pérez-Camacho et al. 1995, 2014). In the case of the Ría de Ares-Betanzos, the 271 annual mean flesh yield seems to be not dictated by the upwelling intensity but by the 272 average continental runoff (Fig. 2d). What the intensity of upwelling seems to affect is the 273 net increase of the $C I$ of the mussels cultured in the Ria de Ares-Betanzos throughout the 274 year (Fig. 2e). Orographic, hydrological and hydrographic differences are behind the 275 contrasting oceanographic behaviour of the rías of Arousa and Ares-Betanzos (Alvarez276 Salgado et al., 2011). Our work suggests that the difference in the oceanography of both 277 embayments translates to the quality of cultured mussels too. Again, the low coefficient of 278 determination of the seasonal increase of the flesh yield with the average upwelling index 279 over the upwelling season $\left(\mathrm{R}^{2}=0.44\right)$, prevent us to forecast, but supports the premise of 280 the influence of upwelling on mussel commercial quality posed by Blanton et al. (1987).

The timing of the seasonal minimum of mussels $C I$ is associated with the timing of 282 the early spring spawning event (Villalba et al., 1995; Peteiro et al., 2011; Fuentes- Santos 283 et al., 2016) that, in turns, appears to be conditioned by the average total radiation received 284 by the Ría de Ares-Betanzos during February (Fig. 2f). Global radiation is used here as a 285 foretaste of seawater temperature, which is the variable that dictates the timing of the 286 reproductive cycle of bivalves (Phillippart et al., 2003). Therefore, higher radiation in late 287 winter (February) produces an earlier warming of the surface waters that results in an 288 earlier spring spawning event and a timelier value of $\varphi$, the month when the flesh yield was 289 halfway between the seasonal minimum and the seasonal maximum. 


\subsection{Spatial differences in mussel flesh yield}

Numerous studies have reported that the mussel flesh yield can vary substantially among bivalves cultured in nearby sites within the same embayment (Fernández-Reiriz et al., 1996; Marin et al., 2003; Norkko et al., 2006; Baek et al., 2014), or in proximate locations in a given coastal ecosystem (Okumus and Stirling 1998; Kang et al., 2000; Pérez-Camacho et al., 2013; Irisarri et al., 2015). In this case, our results indicate that the annual mean and seasonal amplitude of the flesh yield is significantly higher in Arnela than in Lorbé. This seems counterintuitive if one considers that Arnela is located in the inner part of the embayment, i.e. closer to the river mouth, and continental runoff has a negative impact on the inter-annual variability of the annual mean $C I$. However, it has been recently suggested that the variability of seston food quality in the Ría de Ares-Betanzos can be explained by an appropriate combination of nutrient loads, pycnocline development and flushing time that is met in the cultivation area of Arnela (Aguiar et al., 2015), where the flushing time is twice than in Lorbe (Duarte et al., 2014). Furthermore, it has been also suggested that the better flesh yield of the mussels from Arnela is related to the lower mussel biomass in that area, with only 40 of the 147 mussel rafts (Alvarez-Salgado et al., 2011), which exerts lower pressure in the standing stock of food available (FernandezReiriz et al. 1996).

\subsection{Mussels flesh yield under climate change}

The empirical relationships obtained in this work between the annual average, seasonal built-up and phenology of the mussel flesh yield with river discharge, coastal 
312 winds and solar radiation provided us with a tool to argue about the quality of harvested 313 mussels in response to future climate scenarios in the study area.

315 subtropical and temperate regimes of the Eastern North Atlantic. Therefore, this area is 316 particularly sensitive to climate change. In fact, a challenged decrease of the intensity and 317 persistence of upwelling favourable winds over the last 50 years has been reported (Barton 318 et al., 2013). Such a decrease seems to be the reason behind the increase in the number of 319 days that the mussel cultivation areas are closed to exploitation because of the occurrence 320 of diarrheic (DSP) and paralytic shellfish poisoning (PSP) toxicity in mussel flesh in the 321 wind-governed southern rías of Vigo, Pontevedra, Arousa and Muros (Alvarez-Salgado et 322 al., 2008) (Fig. 1). In the case of the northern Ría de Ares-Betanzos, which is both river and 323 wind-governed, it has been found that the number of days that Arnela and Lorbé are closed 324 to exploitation during the summer depends on spring continental runoff and the number of 325 days closed during the autumn depends on NE winds intensity during the summer (Alvarez326 Salgado et al., 2011). Concurrently, whereas according to Blanton et al. (1987) mussel flesh 327 yield is related to coastal wind patterns in the southern Ría de Arousa, it is affected not only 328 by coastal winds but also by continental runoff in the Ría de Ares-Betanzos. Our results 329 suggest that an overall decrease of the flesh yield of mussels cultured in the Ría de Ares330 Betanzos should have to occur in parallel to the decrease in upwelling intensity observed 331 from the middle 1960's (Alvarez-Salgado et al., 2008; Pérez et al., 2010). Conversely, 332 future climate scenarios predict a significant intensification of coastal upwelling in the 333 study area during the summer months through the $21^{\text {st }}$ century (Alvarez et al., 2016), which 334 would lead to a recovery of mussel flesh yield. 

357 2011, financed by the European Social Fund.

\section{Conclusions}

\section{Acknowledgements}

The interannual variability observed in the seasonal cycle of the flesh yield of mussels cultured in the Ría de Ares Betanzos, NW Iberian upwelling system, was linked to the primary variables that define the climate of the area: continental runoff, offshore Ekman transport and solar radiation. We observed that (1) continental runoff affected inversely the annual mean flesh yield; (2) offshore Ekman transport affected positively the seasonal increase of the flesh yield through the spring and summer; and (3) solar radiation affected positively the timing of the spring spawning and, therefore, the timing of the seasonal increase of the flesh yield. The linear correlations obtained between the response and explanatory variables do not present high determination coefficients, which prevent us to make quantitative predictions However, they can be helpful indicators of the seasonal and interannual variability of mussels flesh yield or being used to argue about the impact of future climate scenarios on mussel flesh yield in our area.

We are grateful to Dolores Fernández Vázquez (PROINSA Mussel Farm Managing Director) and the PROINSA Mussel Farm team, especially O. Fernandez Rosende, T. Criado, H. Regueiro and M. García for technical support. I. Fuentes-Santos helped with the statistical analyses. Useful suggestions and comments by two anonymous reviewers have contributed to improve the manuscript. This study was funded by the EU H2020 project ClimeFish (EU 677039), PROINSA-CSIC contract (CSIC0704101100001), and CSIC project (PIE 201540E107). V. Vinseiro was funded by contract CSIC-I3P-JAE Tech 


\section{References}

Aguiar, E., Fuentes-Santos, I., Labarta, U., Álvarez-Salgado, X.A., Fernández-Reiriz, M.J., 2015. Empirical modelling of seston food quality based on environmental factors in a mussel culture area (NW Iberian upwelling system). Mar. Ecol. Prog. Ser. 536, 89-105.

Álvarez, I., Lorenzo, M.N., deCastro, M., Gómez-Gesteira, M., 2016. Coastal upwelling trends under future warming scenarios from the CORDEX project along the Galician coast (NW Iberian Peninsula). Int. J. Climatol., doi: 10.1002/joc.4927.

Álvarez-Salgado, X.A., Figueiras, F.G., Fernández-Reiriz, M.J., Labarta, U., Peteiro, L., Piedracoba, S., 2011. Control of lipophilic shellfish poisoning outbreaks by seasonal upwelling and continental runoff. Harmful Algae 10, 121-129.

Álvarez-Salgado, X.A., Labarta, U., Fernández-Reiriz, M.J., Figueiras, F.G., Rosón, G., Piedracoba, S., Filgueira, R., Cabanas, J.M. 2008. Renewal time and the impact of harmful algal blooms on the extensive mussel raft culture of the Iberian coastal upwelling system (SW Europe). Harmful Algae 7, 849-855.

Álvarez-Salgado, X.A., Rosón, G., Pérez, F.F., Figueiras, F.G., Ríos, A.F., 1996. Nitrogen cycling in an estuarine upwelling system, the Ría de Arousa (NW Spain) II: Spatial differences in the short-time-scale evolution of fluxes and net budgets. Mar. Ecol. Prog. Ser. 135. 275-288.

Baek, M.J., Lee, Y.-J., Choi, K.-S., Lee, W.C., Park, H.J., Kwak, J.H., Kang, C.-K., 2014. Physiological disturbance of the Manila clam, Ruditapes philippinarum, by altered environmental conditions in a tidal flat on the west coast of Korea. Mar. Poll. Bull. 78, $137-145$. 
Bakun, A. 1973. Coastal upwelling indices, west coast of North America, 1946-71. NOAA Technical Report, Special Scientific Reports - Fisheries vol. 671, US National Marine Research Service.

Barton E.D., Field, D.B., Roy, C., 2013. Canary current upwelling: More or less? Prog. Oceanogr. 116, 167-178.

Blanton, J.O., Tenore, K.R., Castillejo, F.F., Atkinson, L.P., Schwing, F.B., Lavin, A., 1987. The relationship of upwelling to mussel production in the Rías on the western coast of Spain. J. Mar. Res. 45, 497-511.

Duarte, P., Álvarez-Salgado, X.A., Fernández-Reiriz, M.J., Piedracoba, S., Labarta, U., 2014. A modelling study on the hydrodynamics of a coastal embayment occupied by mussel farms (Ría de Ares-Betanzos, NW Iberian Peninsula). Estuar. Coast. Shelf Sci. $147,42-55$.

Fernández-Reiriz, M.J., Labarta, U., Babarro, J.M.F., 1996. Comparative allometries in growth and chemical composition of mussel (Mytilus galloprovincialis Lmk) cultured in two zones in the Ría de Sada (Galicia, NW Spain). J. Shellfish Res. 15, 349-354.

Filgueira, R., Comeau, L.A., Landry, T., Grant, J., Guyondet, T., Mallet, A., 2013. Bivalve condition index as an indicator of aquaculture intensity. A meta-analysis. Ecol. Ind. 25, $215-229$.

Halpern, B.S. and others, 2008. A global map of human impact on marine ecosystems. Science $319,948-952$.

Irisarri, J., Fernández-Reiriz, M.J., Labarta, U., 2015. Temporal and spatial variations in proximate composition and Condition Index of mussels Mytilus galloprovincialis cultured in suspension in a shellfish farm. Aquaculture 435, 207-216. 
Kang, C.K., Park, M.S., Lee, P.Y., Choi, W.J., Lee, W.C., 2000. Seasonal variations in condition, reproductive activity, and biochemical composition of the Pacific oyster, Crassostrea gigas (Thunberg) in suspended culture in two coastal bays of Korea. J. Shellfish Res. 19, 771-778.

Knights, A.M., 2012. Spatial variation in body size and reproductive condition of subtidal mussels: considerations for sustainable management. Fish. Res. 113, 45-54.

Labarta, U., Fernández-Reiriz, M.J., Pérez-Camacho, A., Pérez-Corbacho, E., 2004. Mussels-farmers, sea, mussels: a bioeconomic perspective (in Spanish). Fundación Caixa Galicia.

Lucas, A., Beninger, P.G., 1985. The use of physiological condition indices in marine bivalve aquaculture. Aquaculture 44, 187-200.

Marin, M.G., Moschino, V., Deppieri, M., Lucchetta, L., 2003. Variations in gross biochemical composition, energy value and condition index of $T$. philippinarum from the Lagoon of Venice. Aquaculture 219, 859-871.

Mathieu, M., Lubet, P., 1993. Storage tissue metabolism and reproduction in marine bivalves: a brief review. Invert. Reprod. Dev. 23, 123-129.

Nogueira, E., Pérez, F.F., Ríos, A.F., 1997. Seasonal patterns and long-term trends in an estuarine upwelling ecosystem (Ría de Vigo, NW Spain). Estuar. Coastal Shelf Sci. 44, $285-300$.

Norkko, J., Thrush, J.F. 2006. Ecophysiology in environmental impact assessment: implications of spatial differences in seasonal variability of bivalve condition. Mar. Ecol. Prog. Ser. 326, 175-186. 
425 Okumus, I., Stirling, H.P., 1998. Seasonal variations in the meat weight, condition Index 426 and biochemical composition of mussels (Mytilus edulis L.) in suspended culture in two 427 Scottish sea lochs. Aquaculture 159, 249-261.

428 Orban, E., Di Lena, G., Nevigato, T., Casini, I., Marzetti, A., Caproni, R., 2002. Seasonal 429 changes in meat content, condition index and chemical composition of mussels (Mytilus 430 galloprovincialis) cultured in two different Italian sites. Food. Chem. 77, 57-65.

431 Orban, E., Di Lena, G., Nevigato, T., Casini, I., Caproni, R., Santaroni, G., Giulini, G., 432 2007. Nutritional and commercial quality of the striped venus clam, Chamelea gallina, 433 from the Adriatic sea. Food. Chem. 101, 1063-1070.

434 Pérez-Camacho, A., Labarta, U., Beiras, R., 1995. Growth of mussels (Mytilus edulis 435 galloprovincialis) on cultivation rafts: influence of seed source, cultivation site and 436 phytoplankton availability. Aquaculture 138, 349-362.

437 Pérez-Camacho, A., Labarta, U., Vinseiro, V., Fernández-Reiriz, M.J., 2013. Mussel 438 Production Management: Raft culture without thinning-out. Aquaculture 406-407, 172$439 \quad 179$.

440 Pérez-Camacho, A., Aguiar, E., Labarta, U., Vinseiro, V., Fernández-Reiriz, M.J., Álvarez441 Salgado, X.A., 2014. Ecosystem-based indicators as a tool for mussel culture 442 management strategies. Ecol. Ind. 45, 538-548.

443 Pérez, F.F., Padín, X.A., Pazos, Y., Gilcoto, M., Cabanas, J.M., Pardo, P.C., Doval, M.D., 444 Fariña-Busto, L., 2010. Plankton response to weakening of the Iberian coastal 445 upwelling. Global Change Biol. 16, 1258-1267. 
Peteiro, L.G., Labarta, U., Fernández-Reiriz, M.J., Álvarez-Salgado, X.A., Filgueira, R., Piedracoba, S., 2011. Influence of intermittent-upwelling on Mytilus galloprovincialis settlement patterns in the Ría Ares-Betanzos. Mar. Ecol. Prog. Ser. 443, 111-127.

Phillippart, C.J.M., van Aken, H.M., Beukema, J.J., Bos, O.G., Cadée, G.C., Dekker, R., 2003. Climate-related changes in recruitment of the bivalve Macoma balthica. Limnol. Oceanogr. 48, 2171-2185.

Polasky, S., Carpenter, S.R., Folke, C., Keeler, B., 2011. Decision-making under great uncertainty: environmental management in an era of global change. Trends Ecol. Evol. $26,398-404$.

Sasikumar, G., Krishnakumar, P.K., 2011. Aquaculture planning for suspended bivalve farming systems: the integration of physiological response of green mussel with environmental variability in site selection. Ecol. Ind. 11, 734-740.

Smaal, A.C., Widdows, J., 1994. The scope for growth of bivalves as an integrated response parameter in biological monitoring, p. 247-267. In K.J.M. Kramer [ed.], Biomonitoring of coastal waters and estuaries. CRC Press.

Strahler, A.N., 1963. Physical geography. John Wiley and Sons.

Suárez, P., Ruiz, Y., Alonso, A., San Juan, F., 2013. Organochlorine compounds in mussels cultured in the Ría of Vigo: accumulation and origin. Chemosphere 90, 7-19.

Tenore, K.R., González, N., 1975. Food chain patterns in the Ría de Arousa, Spain: an area of intense mussel aquaculture. Paper presented at the $10^{\text {th }}$ European Symposium of Marine Biology, Ostende, Belgium. Wetteren: IZWO/Universa Press: Wetteren. 
467 Tenore, K.R., Boyer, L.F., Cal, R.M., Corral, J. and others, 1982. Coastal upwelling in the 468 Rías Bajas, NW Spain: contrasting benthic regimes of the Rías de Arousa and the 469 Muros. J. Mar. Res. 40, 701-722.

470 Villalba, A., 1995. Gametogenic cycle of cultured mussel, Mytilus galloprovincialis, in the 471 bays of Galicia (NW Spain). Aquaculture 130, 269-277. 


\section{$472 \quad$ Figure legends}

473 Fig. 1. The mussel cultivation areas of Arnela and Lorbé (Ría de Ares-Betanzos, NW

474 Iberian Peninsula) are shown. Rivers Eume and Mandeo, the $2^{\circ} \times 2^{\circ}$ cell centred at $43^{\circ} \mathrm{N}$

$47511^{\circ} \mathrm{W}$ where geostrophic winds were calculated and the meteorological station of CIS

$476 \quad$ Ferrol are also positioned.

477

478 Fig. 2. Time course of the (A) annual mean, (B) seasonal amplitude and (C) diphase of the 479 mussel flesh yield or condition index $(C I)$ in the cultivations areas of Arnela and Lorbé; and 480 relationship of (D) the annual mean $C I$ with the annual mean continental runoff $(Q r),(\mathbf{E})$ 481 the seasonal amplitude of $C I$ with average offshore Ekman transport from April to August $482\left(-Q_{L}\right)$, and $(\mathbf{F})$ the diphase of $C I$ with the average global radiation during February $(G)$. 483 White dots and continuous lines correspond to Arnela and blank dots and dashed lines 484 correspond to Lorbé.

486 Fig. 3. Time-course of the (A) annual mean of the continental runoff, $(\mathbf{B})$ average April487 September offshore Ekman transport and (C) average February global radiation. 
Table 1. Fitting parameters of the average seasonal cycles of mussel flesh yield or 489 condition index $(C I)$, freshwater discharge $(Q r)$, offshore Ekman transport $\left(-Q_{\mathrm{L}}\right)$ and global 490 radiation $(G)$ over the period 2001-2012. Annual mean, seasonal amplitude and diphase 491 are the parameters $b_{1}, b_{2}$ and $b_{3}$ in Eq. 1 . The parameter $b_{3}$ indicates the month when the 492 seasonal minimum of each variable is achieved.

\begin{tabular}{|c|c|c|c|c|c|}
\hline & Annual mean & Seasonal amplitude & Diphase & $\mathrm{R}^{2}$ & $p$ \\
\hline$C I$ (Arnela) & $23.4 \pm 0.4$ & $6.0 \pm 0.6$ & $3.3 \pm 0.2$ & 0.54 & $<0.001$ \\
\hline$C I$ (Lorbé) & $21.9 \pm 0.3$ & $4.3 \pm 0.5$ & $3.6 \pm 0.2$ & 0.42 & $<0.001$ \\
\hline$Q \mathrm{r}$ & $29 \pm 2$ & $24 \pm 2$ & $7.2 \pm 0.2$ & 0.41 & $<0.001$ \\
\hline$-Q_{\mathrm{L}}$ & $-46 \pm 48$ (n.s.) & $433 \pm 68$ & $0.6 \pm 0.3$ & 0.23 & $<0.001$ \\
\hline$G$ & $1267 \pm 12$ & $841 \pm 17$ & $0.28 \pm 0.04$ & 0.94 & $<0.001$ \\
\hline
\end{tabular}




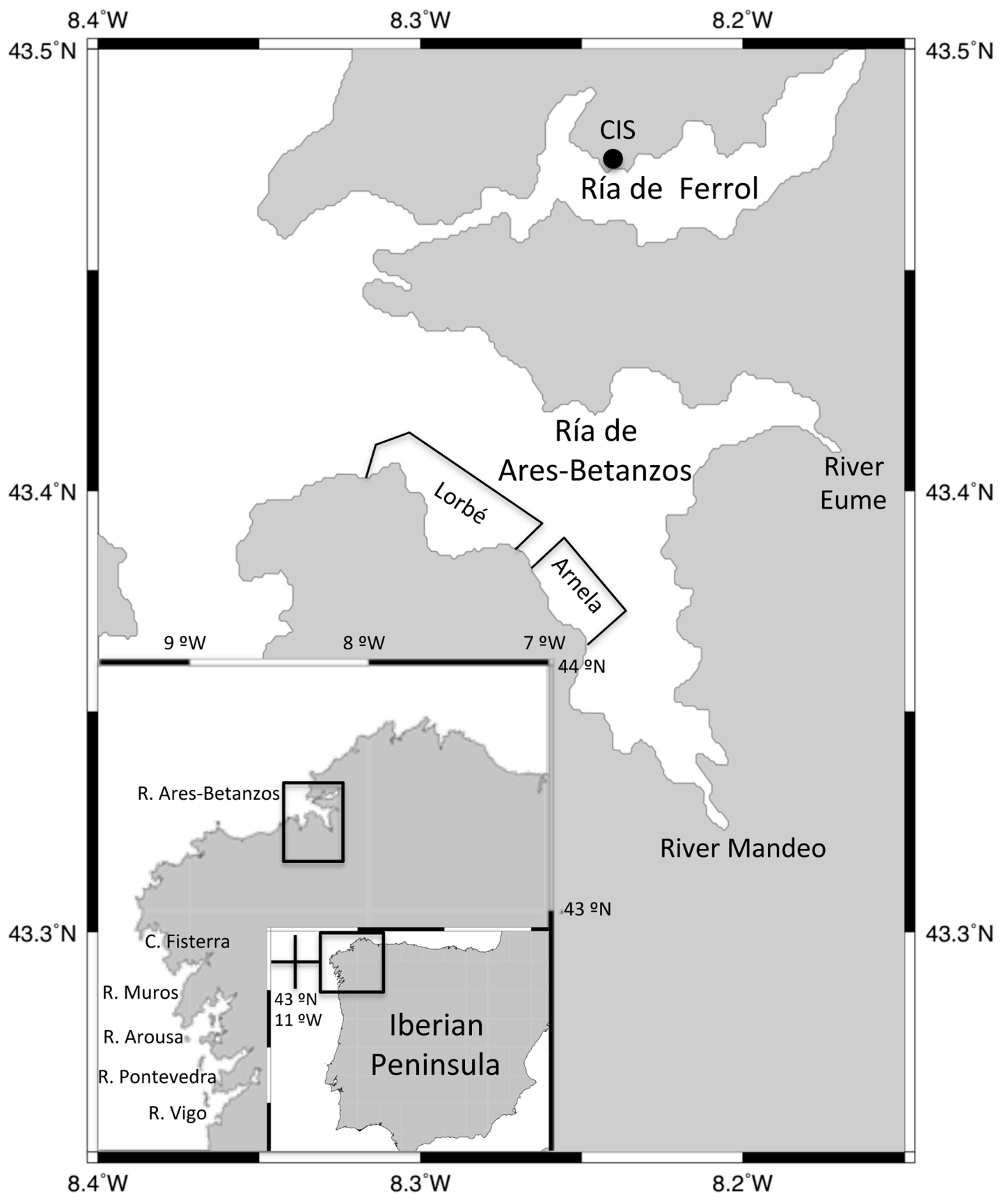



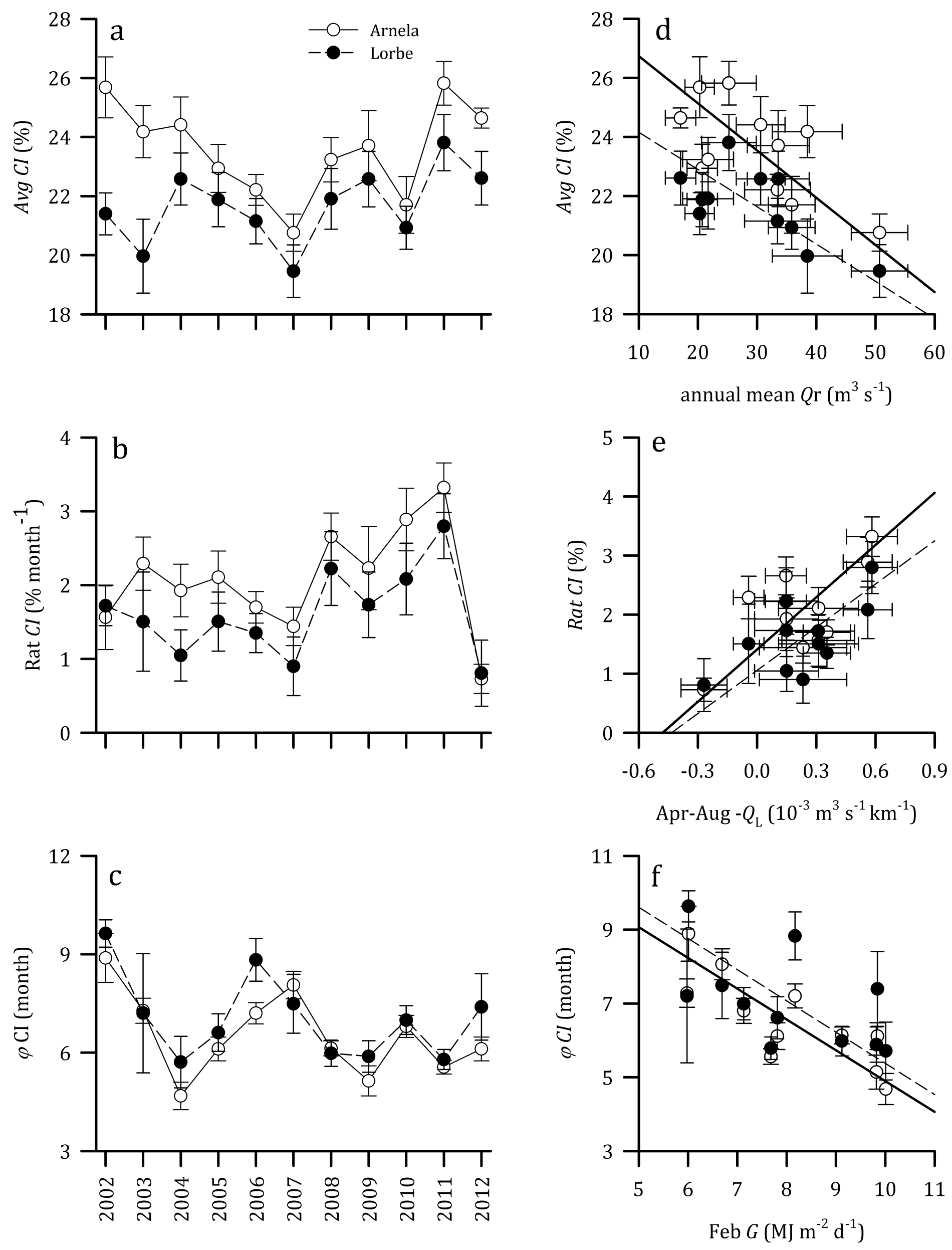

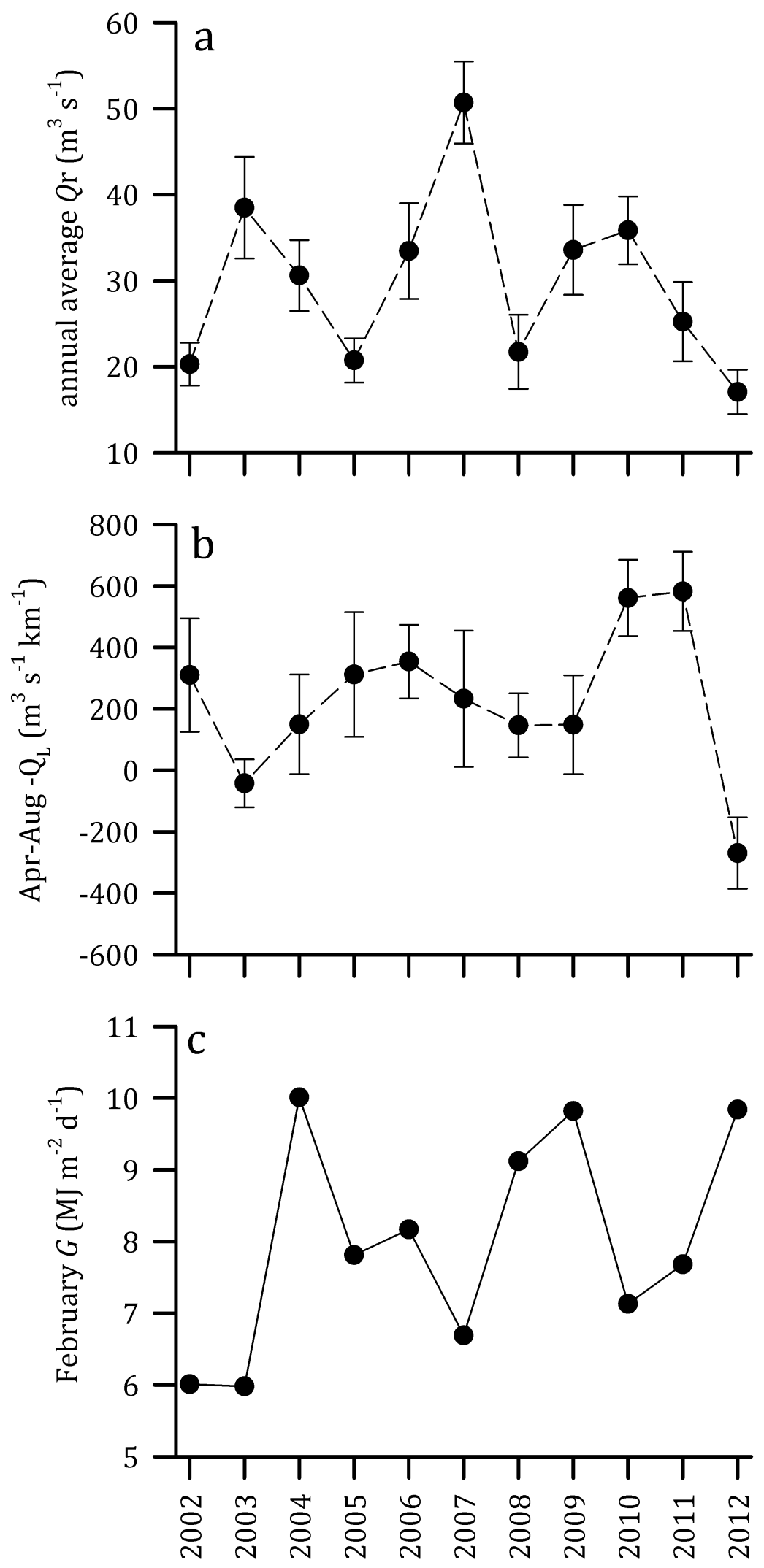


\section{Appendix}

Table A1. Monthly average mussel flesh yields (in \%) for the cultivation areas of Arnela and Lorbé in the Ría de Ares-Betanzos (NW Spain) between 2001 and 2012. Each flesh yield data was calculated as the percentage of the total weight of $1 \mathrm{~kg}$ of mussels that is meat weight. Numbers in brackets indicate the number of flesh yield data used to obtain the monthly average values.

\section{Arnela}

\begin{tabular}{|c|c|c|c|c|c|c|c|c|c|c|c|c|}
\hline & Jan & Feb & Mar & Apr & May & Jun & Jul & Aug & Sep & Oct & Nov & Dec \\
\hline 2001 & & & & & & & & & $36.6(11)$ & $25.3(1)$ & & $31.5(3)$ \\
\hline 2002 & $28.4(21)$ & & & & & $22.9(6)$ & $19.2(1)$ & $24.5(13)$ & $25.8(19)$ & & $29.0(2)$ & \\
\hline 2004 & & $17.5(3)$ & & $24.8(6)$ & $24.6(5)$ & $27.2(13)$ & $29.6(9)$ & & $29.6(6)$ & & 25.9 (19) & \\
\hline 2005 & & $16.5(2)$ & $19.5(3)$ & & $17.7(11)$ & $21.3(18)$ & $26.3(4)$ & 30.9 (4) & $28.0(4)$ & & $27.6(29)$ & \\
\hline 2006 & & & $17.5(8)$ & & $17.6(7)$ & $20.6(40)$ & $20.5(7)$ & & & $26.9(15)$ & $25.1(5)$ & \\
\hline 2009 & $18.7(8)$ & & $21.9(3)$ & $12.4(2)$ & $24.6(8)$ & $28.3(30)$ & $31.6(3)$ & $29.2(5)$ & $27.9(6)$ & $28.0(11)$ & $26.1(30)$ & $27.1(1)$ \\
\hline 2010 & & & $12.9(9)$ & $15.7(6)$ & 13.9 (14) & $16.1(34)$ & $22.4(19)$ & & $34.1(4)$ & & & $24.6(14)$ \\
\hline 2011 & $21.2(12)$ & $17.6(7)$ & $15.0(1)$ & $15.6(4)$ & $21.4(33)$ & $30.4(5)$ & $35.0(15)$ & $37.0(1)$ & 32.9 (19) & $30.4(14)$ & $26.9(13)$ & $23.9(16)$ \\
\hline 2012 & $24.1(4)$ & $22.0(1)$ & & & $24.6(3)$ & $24.1(9)$ & $25.1(14)$ & & $26.7(7)$ & & $25.5(21)$ & \\
\hline
\end{tabular}




\section{Lorbé}

\begin{tabular}{|c|c|c|c|c|c|c|c|c|c|c|c|c|}
\hline & Jan & Feb & Mar & Apr & May & Jun & Jul & Aug & Sep & Oct & Nov & Dec \\
\hline 2001 & & & & & & & $23.7(3)$ & $27.1(5)$ & $32.0(24)$ & $27.6(60)$ & $22.1(19)$ & $26.8(7)$ \\
\hline 2002 & $26.6(3)$ & $25.4(5)$ & & & & $18.0(1)$ & $13.8(4)$ & $17.5(4)$ & $21.0(20)$ & $24.2(13)$ & $21.6(71)$ & $20.8(32)$ \\
\hline 2004 & & $18.3(1)$ & & $22.5(30)$ & $22.5(11)$ & $19.8(22)$ & $24.4(15)$ & $26.2(21)$ & $27.1(2)$ & $24.4(63)$ & $24.7(34)$ & \\
\hline 2005 & & $18.5(3)$ & $20.4(7)$ & & $14.0(14)$ & $21.8(37)$ & $25.0(6)$ & $23.6(7)$ & $27.9(4)$ & $25.1(10)$ & $23.3(30)$ & $22.2(16)$ \\
\hline 2006 & $22.5(2)$ & & $18.6(6)$ & $18.5(10)$ & $13.1(10)$ & $15.9(13)$ & & & & & $22.8(69)$ & $20.1(57)$ \\
\hline 2009 & $21.6(12)$ & & $18.3(3)$ & $13.0(3)$ & & $25.5(20)$ & $28.8(6)$ & $25.5(25)$ & $26.4(42)$ & $25.0(26)$ & $21.3(8)$ & $23.2(3)$ \\
\hline 2010 & $22.2(6)$ & $18.8(14)$ & $17.2(4)$ & $18.4(11)$ & $15.2(8)$ & $15.7(5)$ & $24.4(7)$ & 22.9 (18) & & $27.2(19)$ & $24.0(50)$ & $22.5(11)$ \\
\hline 2011 & & $19.1(6)$ & $16.6(14)$ & $16.3(29)$ & $20.0(32)$ & $19.8(30)$ & $29.7(3)$ & $37.0(3)$ & $32.0(1)$ & 29.9 (39) & $27.4(38)$ & $26.2(14)$ \\
\hline 2012 & $22.9(14)$ & $20.5(10)$ & & & $19.3(2)$ & $20.6(5)$ & $26.0(1)$ & & $21.5(8)$ & $22.5(4)$ & & $25.9(8)$ \\
\hline
\end{tabular}


Figure A1. Spatial distribution of the mussel flesh yields data for the cultivation areas of Arnela and Lorbé in the Ría de Ares-Betanzos (NW Spain). Each mark corresponds to an individual mussel raft /long-line where the mussel flesh yield was obtained. The symbols (see legend) indicate the number of times that each raft/long-line was visited to obtain the flesh yield over the study period 2001-2012. This chart illustrates that the data were not obtained on a regular temporal and spatial basis but according to the management strategy of the farmer.

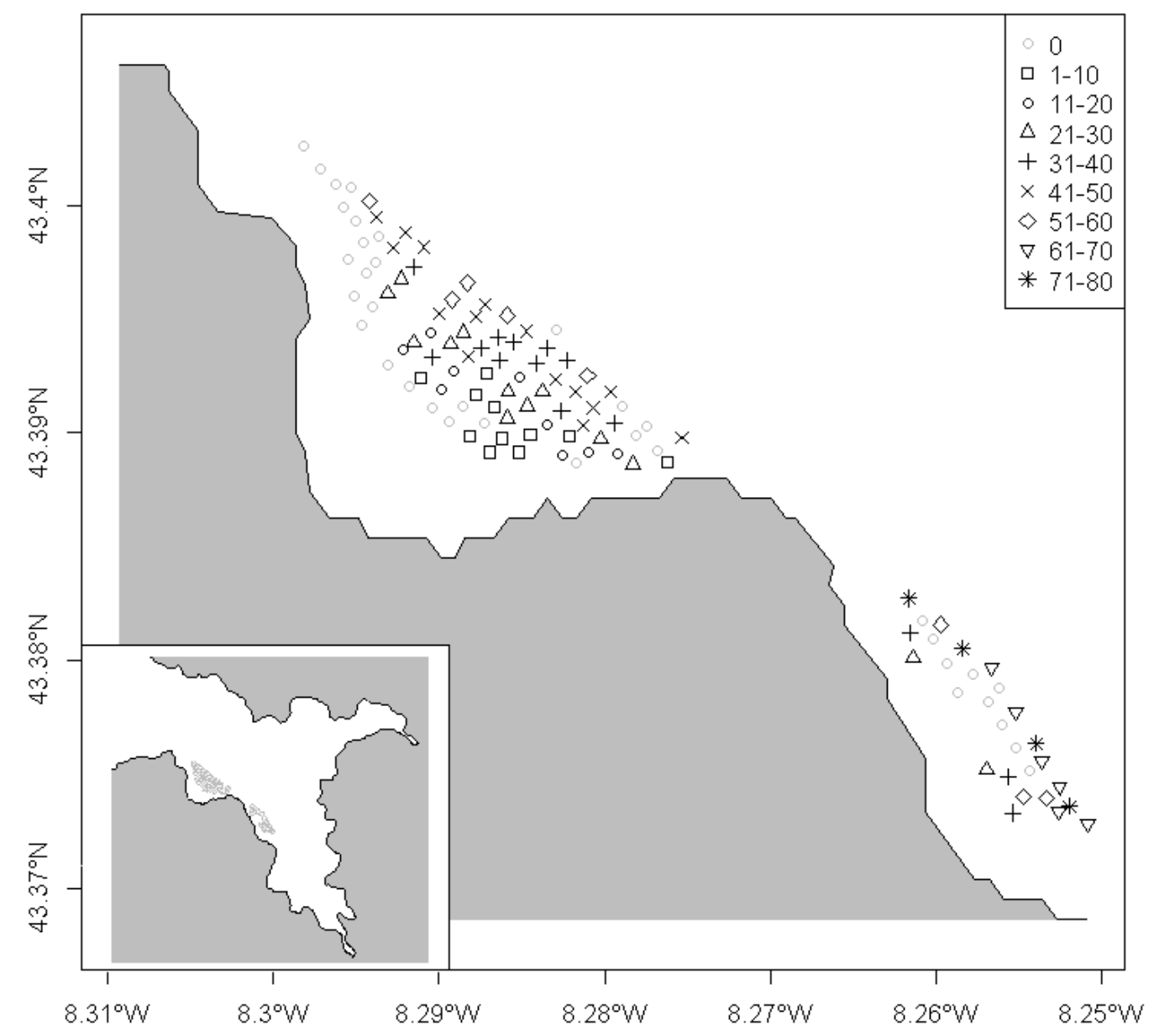


Figure A2. Time series of the monthly box plots of the (a) mussel flesh yield of Arnela; (b) mussel flesh yield of Lorbé; (c) volume discharged by the rivers Eume and Mandeo; and (d) offshore Ekman transport.
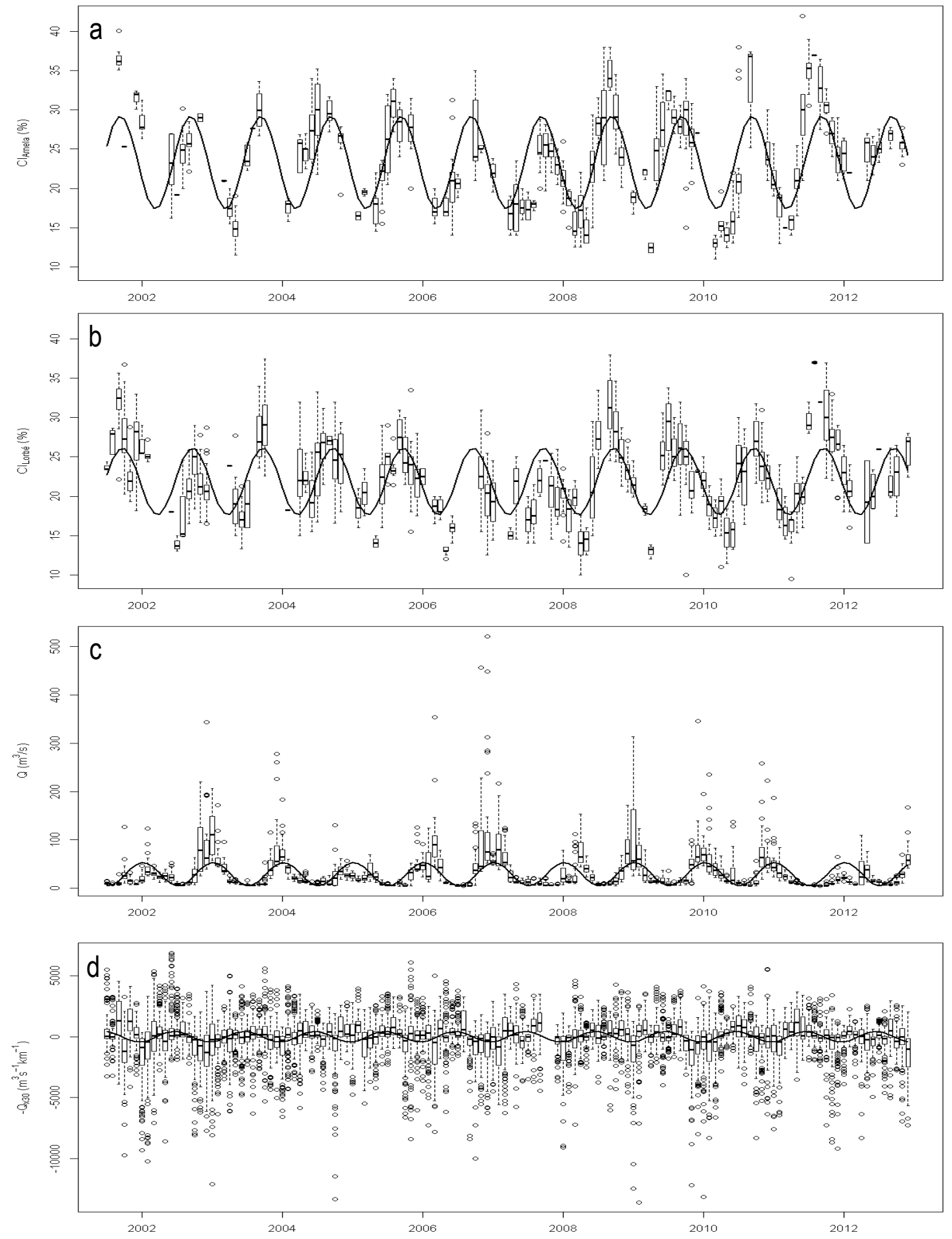
Figure A3. Individual year seasonal cycles of the mussel flesh yield for the cultivation areas of Arnela and Lorbé. Note that the years are defined from November to October. Solid and dotted lines represent the fitting of monthly average data to the harmonic Eq. 3 for Arnela and Lorbe, respectively.
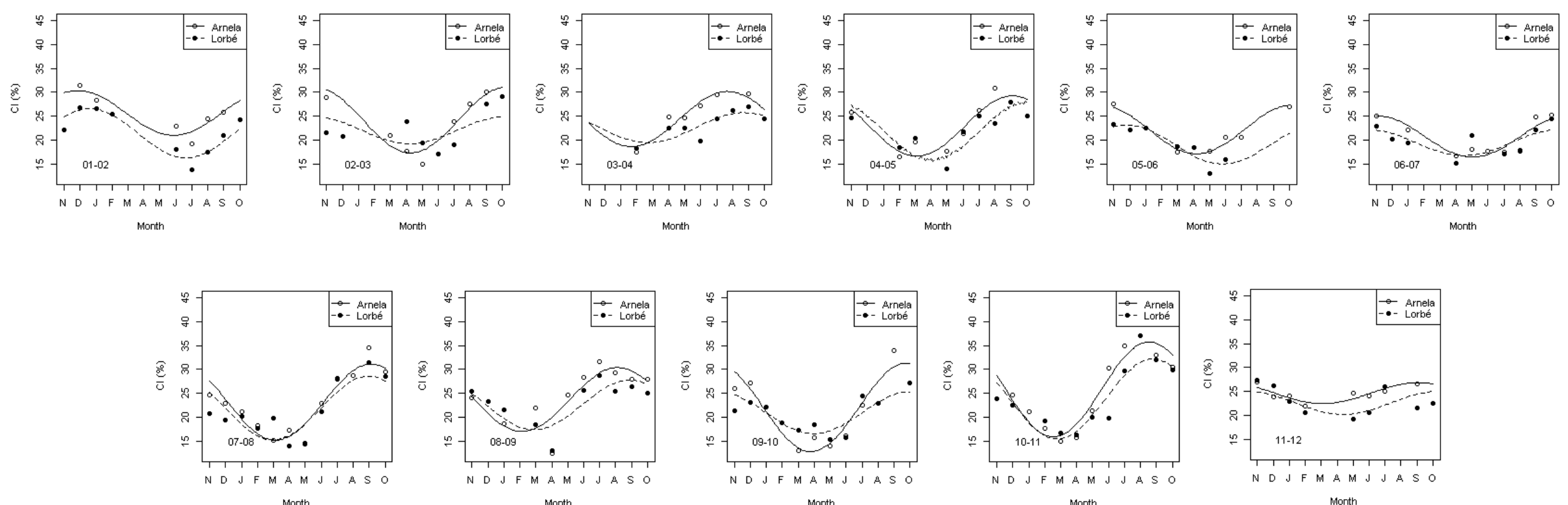

Morth

Morth 